\title{
Direito Público
}

\section{A. de Sampáio Dória}

BASES NA ORGANIZAÇÃO POLfTICA DOS HOMENS LIVRES. PREVENTIVOS CONTRA ABUSOS DO PODER.

Que é o que se pretende, acima de tudo, com a organização do estado num povo livre?

A independência do país, a ordem pública, a segurança jurídica, o bem geral, que, sendo o bem de todos, é bem para cada qual.

Sobre isto, importa conhecer, como preliminar, duas aberrações.

Uma é a concepção de que os indivíduos existem para o estado, e não o estado para os indivíduos. E' pregão de déspotas. Está nos evangelhos ter vindo Cristo ao mundo para salvar o homem, e não para imolá-lo á sociedade, que, sem o homem, não é nada, e nunca existiu. Nem mesmo tem conteúdo o sacrifício de cada um em benefício de todos. 0 benefício geral, como a idéia genérica da côr em relação ás cores concretas, é a generalização, ou o que houver de comum nos benefícios individuais. Mas, se cada cidadão é inutilizado ou anulado de alto a baixo, que resta, como bem de todos eles? O que fica, é, sem nenhuma duvida, a satisfação pessoal dos dirigentes. Nada mais. 
Em tempo de guerra, compreende-se que o estado exija de todos o sacrifício, até da vida, em defesa da pátria. Nenhum povo deixa, em tal emergência, de praticar este princípio. Mas, em tempo de paz, só algumas nações instituem a mesma subordinação, em caráter permanente. As democráticas a repelem por irracional ou tresloucada. Em verdade, o estado, que o homem organiza, se destina ao bem do homem, e não à sua desgraça. As sociedades se formam em função dos indivíduos, por eles e para eles. E, nas sociedades, a organização política, ou estado, surge, mas é para garantir, igualmente, a cada um a liberdade, isto é, fazer ou deixar de fazer o que, generalizado, não destrúa nem prejudique a vida social. Nunca, para suprimir aos homens a dignidade da existência. E' no reconhecimento dos direitos do homem que reside a razão primária ou de ser do estado. Fóra disto, o estado semelharia não a uma bençam dos povos sensatos, mas a uma catástrofe dos povos desgraçados.

Outra aberração nefasta é a concepção de uma soberania idêntica ao arbítrio de um déspota, ou á vontade do povo, onipotência suprema, e nada mais. E' concepção que não corresponde à realidade por inteiro dos fatos. Ao lado do fenômeno patológico, que se encontra a cada passo, de uma soberania idêntica à vontade de um rei, ou aos impulsos da plebe amotinada, também se observa, nos estados em que o soberano é o povo organizado, como na Inglaterra, na Belgica, nos Estados Unidos, na França, ou na Suissa, que a vontade soberana, longe de ser um poder supremo para seja o que for, tem objetivos inequivocos, imutáveis. Onipotência, certo; mas para o bem social. Não tem, nem póde ter este poder o propósito de reduzir, por exemplo, a nação a colónia de outros povos, nem é natural que deprima, ou suprima, no homem, a sua personalidade. A soberania, nos povos democráticos, dá o que póde, para manter, no exterior, a paz e a independência do país, e promover, dentro das frontei- 
ras, a segurança jurídica, a assistência coletiva, os interesses gerais. A soberania, em suma, cuja organização é o estado, não deve ser, embóra tenha sido, e seja aqui e ali, ainda hoje, a onipotência assim para o bem como para o mal. Dentro das leis que presidem a conservação e desenvolvivimento da natureza humana, organiza-se a coacção social, sob a forma de estado, para manter, em face de outros povos, a independência da nação, e para assegurar, dentro do país, a cada cidadão, fazer ou deixar de fazer o que, mesmo generalizado, não obste à existência próspera do todo. A doutrina da identidade da soberania com a vontade do povo, ou a vontade dos imperantes, sem uma finalidade objetiva e precisa, seria aberrante do senso comum. Investidos alguns homens da força do direito contra o crime, não é natural que a transformem em força do crime contra o direito.

E o que ainda mais agrava o problema, é que, mesmo em doutrina, o sofisma de uma soberania idêntica à vontade do povo, arbitrária, não se destróe com facilidade.

Em primeiro logar, como determinar, com precisão ciêntífica, os limites objetivos, para além dos quais o exercício do poder público resvala do justo para o injusto, do natural para o patológico, do que deve para o que não deve? A liberdade, como produto da vida social, é faculdade de ação compatível com a vida próspera da sociedade. Mas onde está esta linha de compatibilidade? Quais são as condições de vida e desenvolvimento da sociedade, cujo respeito são as fronteiras naturais da liberdade? Ver com acerto onde se traça a linha de compatibilidade da ação individual com a existência da sociedade, ou, vale dizer, lograr a determinação exata do direito, não é tarefa de um homem, mas, como a formação de qualquer outra ciência, é tarefa de gerações, através dos séculos. Em todos os tempos, e por toda parte, vão os juristas normalizando, na observação das sociedades, a ciência do direito. As ações sociais dos indivíduos constituem uma trama confusa de causas e efeitos, e as relações constantes entre estes efeitos e estas causas, são leis, 
que, quando digam respeito à conservação e desenvolvimento do homem e da sociedade, se dizem jurídicas.

Em segundo lugar, embóra cáiba à ciência determinar o direito, quem o torna obrigatório em leis são os políticos, os estadistas, os governantes. O soberano, isto é, o que exercer a soberania, é o juiz inapelavel da competência da soberania. Mesmo nas democracias, vive o povo, afinal, sob o predomínio, consentido embóra, de alguns chefes que o conduzem. Em nome próprio, ou em nome de outrem, a realidade é que são sempre homens que ditam as leis.

Mas estes homens, evidentemente, não são deuses. Muito longe estão mesmo de semi-deuses. Ainda quando superiores, continuam faliveis e parciais. Neste caso, si se der que estes homens, por desvios de inteligência, ou impulsos de paixões, em vez de converterem em leis o direito, pratiquem atos em detrimento dele? $\mathrm{Si}$, em vez de inflexíveis em filar pela gola os delinqüêntes, entrarem eles próprios, por ambição política, ou vingança, a trair, a oprimir, a rapinar e assassinar?

O povo, depois de lhes ter confiado as forças armadas, e o tesouro público, fica, do seu lado, desarmado, à espera das ordens, a que é obrigado a obedecer. Não são raros, na história dos povos, os atentados oficiais até à dignidade da vida. Nesta conjunctura, como ha de o povo ludibriado defender-se dos governos, que os desgracem, restaurando a legitimidade do poder? Apelando para as armas?

Mas as revoluções, além de semear infortúnios novos, agravam, sem quasi excepção, os males que as tenham gerado. Enquanto puder o povo suportar esses males, é mais prudente fugir, até o último instante, aos horrores da guerra civil, cujas feridas sangram gerações, sem organizar a ordem jurídica.

E' a lição de bom senso de S. Tomás de Aquino: "Se a tirania não for excessiva, aconselha, é preferivel tolerar em paciência seu mal, que expôr-se a conseqüências piores em caso de derrota ou mesmo de êxito. Porque, no primeiro caso o tirano vencedor, provocado, se torna mais cruel; no 
segundo caso, discórdias civis são de temer, seja durante a reação, seja depois quando se trate de organizar o novo governo. O mais claro resultado destas discussões é suscitar outro tirano que, temendo a sorte do seu antecessor, se torne ainda mais despótico por ele"

Mas, quando excessiva, quando os governantes, odiosos e odientos, como no bolchevismo russo, insistem em anular, por sistema, as vantagens do estado, opondo seu arbítrio à liberdade, confiscando por cubiça a propriedade, destruindo em proveito próprio a segurança jurídica, então o dever dos que tiverem força e personalidade, é sacudir por terra o jugo dos déspotas, ou caudilhos, para implantar, em bases mais sólidas, na linguagem da proclamação norte-americana, um regime que assegure ao povo o direito de viver e de ser feliz.

A grande sabedoria, porém, a sabedoria prática, que transparece na experiência dos povos, está na adoção de medidas que previnam os abusos do poder. Na fabricação, por exemplo, das belonaves, se vão fazendo, a cada experiência, alterações no seu mecanismo, para evitar os desastres que vilimam. Para-quedas por sobre as nuvens nos enguiços dos aviões são o último recurso, como, para os povos em desespero, as revoluções. O que é prudente, é ir aperfeiçoando o aparêlho, para lhes evitar o mau funcionamento. Tal no aparelhamento do estado representativo: perfeições sucessivas que os desastres sugerem, vão evitando, ou atenuando, de um lado, as demasias do povo soberano, e, do outro lado, os abusos de poder nas mãos dos representantes.

Não é preciso apelar para o governo direto. Os excessos de autoridade das multidões são ainda mais deletérios, que os abusos dos reis, ou a truculência dos caudilhos. Os tribunais da plebe, na praça pública, enrubecem de horrores páginas e páginas da história. Os morticínios da revolução franceza as carnificinas da revolução russa, as tragédias da revolução espanhola, dão a medida do que costumam ser as decisões da multidão desenfreiada, ou das "frentes populares", esquecidas do direito. Razão por isto 
assistia a Voltaire, quando causticava o governo da populaça, como o despotismo da canalha.

Si, contudo, em vez do governo direto integral, forem adotados institutos dele, paralelamente com a representação política, como na Suissa e em muitos estados da União Americana, bem possivel é que se logrem alguns contrapesos eficazes aos abusos do poder representado.

Como, porém, o que tem vingado, em vez do governo direto, é o sistema representativo com ou sem institutos do governo direto, os povos isentos de absolutismos políticos vão introduzindo, na estructura do estado, à medida das necessidades, peças novas, experimentadas, com que se vão acautelando dos abusos emergentes de que a representação política é prolífera.

A construção perfeita de qualquer máquina útil, como um automovel ou avião, exige dos seus construtores conhecimentos de três ordens: primeira, a finalidade da máquina. o que esperam obter dela; segunda, o seu domínio pelo condutor; e, terceira, a técnica da sua construção. O que se espera, por exemplo, de um aeroplano comercial, é a deslocação cômoda, rápida e segura, pelos espaços aéreos. Mas é preciso que o seu piloto o possa dirigir na subida, contrasteá-lo na viagem, e dominá-lo nas descidas. Além disto, para construir, são indispensáveis conhecimentos de técnica, como os referentes ás leis do peso, do equilíbrio, da resistência e durabilidade do material que nele se use.

Tal na estructura do estado. Os estadistas, políticos e juristas, não se sairão bem de sua empresa, se não forem mestres nas três ordens de conhecimentos: primeiro, o que se visa com o estado; segundo, não perder o povo o senhorio do seu governo; terceiro, a técnica da organização do poder.

O que cada povo pretende essencialmente assegurar com a sua organização politica, é a independência do país, a segurança jurídica, e o engrandecimento nacional. Mas, instituindo governantes, é preciso que o povo não perca o leme, como quando se convertam os representantes que eleja, em 
senhores, que o escravizem. Além disto, para que a máquina do estado atinja os seus fins, são os estadistas obrigados a aplicar, na sua organização, certos conhecimentos de técnica, sem os quais a náo do estado, na imagem de Alceu, no VI século antes de Cristo, naufragará, açoitada pela violência das tempestades.

Essas três ordens de conhecimentos correspondem a três grupos de leis: as referentes ás eleições dos governantes pelos governados; as referentes ás instruções dos governados aos governantes; e as referentes à responsabilidade dos governantes perante os governados.

Primeiro, as de livre escolha dos governantes pelos governados. Nada de regimes autocráticos, nem do tipo bolchevista, nem do tipo fascista, que uns e outros são, no fundo, a imposição violenta de imperantes ao povo desarmado e submisso. No mandato político, os dirigentes são meros procuradores do povo. E o seu poder só se legitima, quando assenta no livre consentimento dos governados.

Segundo princípio, para que o povo possa ser o piloto do estado, é o consentimento dos governados na maneira como os representantes se desempenham do mandato que lhes tenham outorgado. Os governantes, certo, não se reduzem a funcionários que cumpram ordens dos representados. Mas não se alçam, por outro lado, a senhores que dêm ordens aos cidadãos. Nem empregados, nem patrões. No direito privado, quando constitue alguem procurador, o que primeiro faz, é dar a este, na procuração que passe, instruções, para agir em seu nome. $O$ procurador, ao exercer o mandato que aceita, delibera por si, em cada caso concreto, mas dentro da vontade do seu cliente, expressa nos poderes que a procuração consagre. Tal na representação política. A nação comete a certo número de pessoas a incumbência do governo. Mas lhes dá, na constituição, nas leis, e, fóra delas, na imprensa, nos partidos e nos comícios, instruções de como devem agir nas linhas gerais. A constituição lhes traça as atribuições, lhes delimita os poderes, e, através do livre exa- 
me dos problemas, e da critica aos homens públicos, a nação põe os dirigentes, em cada problema, ao par do seu pensamento e da sua vontade, para que jamais deliberem contra ela. Sem a fixação e limitação das competências aos órgãos do poder, e sem a liberdade de pensamento, com que os cidadãos examinem e critiquem livremente as soluções, dadas, ou por dar, aos negócios públicos pelos seus representantes, o arcabouço, a armação, a estructuração do estado, nos povos livres, se desconjuntaria ao primeiro sobressalto, e se iria esboroando progressivamente, até o dia em que a catástrofe final o reduza de todo a entulho, a cinza e pó.

$O$ terceiro princípio, ainda na organização constitucional dos povos livres, é o da responsabilização dos governantes, pelo que tenham feito ou deixado de fazer, perante o tribunal supremo da opinião pública. De fato, que adeantaria a eleição de representantes, e as instruções cue recebam, si não pudesse o povo que os eleja, e os instrua, chamá-los a contas periodicamente de como estejam cumprindo os deveres do mandato, si não houvessem sanções que aplaudam a lealḍade, e condenem a traição, com que tenham governado? Si o dono de uma herdade, para a qual nomeic administrador, não pudesse chamá-lo a contas, si não pudesse dispensá-lo, quando faltasse às suas obrigações, ou mantê-lo, enquanto fiel e útil, claro está que deixaria praticamente de ser o dono da herdade. Da mesma fórma, que adeantaria eleger e fixar normas aos governantes, si, depois de investidos no poder, não pudesse chamá-los a contas o povo que os elegeu? Não é porque seja dificílima ou precária esta prestação de contas, que se deva renunciar a estabelecê-la.

Nos casos mais graves, de delitos funcionais, instituemse tribunais que pelo menos à perda do cargo possam condenar os transviados.

Mas, nos casos em que não haja propriamente delitos, mas divergências com a opinião pública, a responsabilidade se vem tornando efetiva, nos grandes povos, mediante uma 
de duas soluções fundamentais. A primeira, pela queda dos gabinetes, ao sabor dos parlamentos, e, complementarmente, pela dissolução da câmara dos deputados, por iniciativa do poder executivo. A segunda, sem a dissolução da câmara, nem distituição do executivo, renovando a nação, livremente, por períodos curtos, em eleições diretas, representantes da sua confiança.

Para se estabelecer a instância popular, em que o chefe do executivo e os legisladores são chamados a contas, impõese, antes de mais nada, a imparcialidade absoluta do poder organizado no processo eleitoral. Nenhuma compressão, desde a indicação dos candidatos, até à proclamação dos eleitos. Não é que não possam os governantes cujo mandato termine, candidatar-se a reeleições. A responsabilização não se anula com o pedido, que façam ao povo, de renovação do mandato expirante. O que lhes é vedado, é interferirem, mesmo só com o prestigio do cargo que exerçam, ou com promessas de emprego, ou ameaças de demissão, em favor de sua candidatura, ou de candidatura da sua simpatia. A nação, para se pronunciar livremente, sentenciando, no veredicto das eleições, sobre si os seus representantes agiram bem ou mal, exige dos poderes constituidos uma atitude de magistrados, a mais inflexivel imparcialidade nos pleitos eleitorais. Do contrário, lá se vai por águas abaixo o magno princípio da responsabilidade, sobretudo nos regimes presidenciais.

Ao lado da abstenção absoluta do governo nas lutas eleitorais, cumpre, para que a opinião pública não perca o comando na máquina do estado, respeitar-se, todos os dias, de manhã a noite, a liberdade do pensamento, e de associação política. Sem o livre exame, sem liberdade de crítica, não se esclareceria nunca a opinião pública, para responsabilizar com eficiência ou proveito, sentenciando com justiça, ou julgando conforme os interesses gerais do momento. Onde a imprensa não for livre, onde se capitularem delitos de opinião, fica o povo sem elementos para pensar com verdade e 
justeza. Os fatos sociais são apresentados a uma só luz aos indivíduos, e, si desde criança estão privados de olhá-los por todos os lados, terminam por pensar como querem que eles pensem. A mentalidade se deforma, e a opinião pública que, nestas condições, acaso se forme, nenhum valor tem, como expressão verdadeira das realidades sociais sobre 0 estado e seus fins.

Por outro lado, sem o direito de associação política, não se formariam nunca os partidos, e, só com opiniōes dispersas e caóticas, só com opiniões puramente individuais, sem unidade, como formar-se a consciência nacional, como força que se imponha, a opinião pública vigilante, que impere?

A organização legal dos partidos políticos para as eleições livres, assim como os tribunais especiais, são, em suma, no regime presidencial, as duas providências capitais, para a efetiva responsabilidade dos governantes. No regime parlamentar, além destas duas, acrescem a renovação dos gabinetes pelas câmaras, e a dissolução das câmaras pelo executivo.

O povo que não puzer todo o seu cuidado em consagrar estes princípios técnicos na organização do estado por que se reja, perde o domínio e a direção da máquina política, que organize, e está mas é no caminho da sua perdição. Quando menos espere, as forças armadas, virando partido político, deliberam em nome do povo, posto que, algumas vezes, para evitar que a anarquia tripudie sobre os direitos mais sagrados. Então, o pulso forte de um ditador pode manter a ordem, mas como um capitão negreiro nas senzalas.

O problema da maior prudência é sistematizar a representação eletiva, para que não se ensejem os golpes de estado, nem proliferem os abusos de poder. Tem o estado por missão magna manter, no exterior, a paz e a independência do país contra agressões estrangeiras, e promover, no interior, a ordem pública, a segurança jurídica, e o engrandecimento coletivo. Mas manter a paz e a independência do país, e promover a ordem, a segurança e o progresso, sem escravizar os cidadãos. 
Eis o grande problema.

Os povos livres têm dado a este problema, nas suas linhas gerais, quasi sempre, a mesma solução, como, para fabricar automóveis, as boas fábricas lançam mão da mesma técnica geral. Aqui e ali, variedades acidentais, mercê das condições geográficas e econômicas, mercê do material humano, raças, religiões e culturas. Mas, em grande parte, e no essencial, as soluções se aproximam.

Qual é, porém, a solução geral, de que se têm valido os povos livres?

Em toda parte, nos estados democráticos, a peça mais importante, na máquina do estado, é a separação de poderes. Não confiar nunca o poder público a um só homem. Mas distribuir o exercício da soberania por três órgãos. Foi o que resultou da experiência universal, e especialmente da experiência inglesa, da francesa, da estadunidense. Onde o princípio da separação não se institua, ou funcione mal, a segurança jurídica terá desaparecido, ou nunca existiu. Näs repúblicas italianas em que os três poderes se achavam reunidos, relembra Montesquieu, a liberdade se encontra menos que nas monarquias. (Esp. das Leis, Liv. XI, Cap. VI). Da mesma fórma, continúa Montesquieu, entre os turcos onde os três poderes são reunidos na cabeça do sultão, "reina tremendo despotismo" A tendência tão do gosto moderno para as autarquias e tribunais administrativos com função legislativa, judiciária e executiva, para administrar a seu arbítrio, e fazer justiça sem lei, é um eclipse da civilização política, um retrocesso nas trevas, onde fuzilam calamidades.

Outra peça de importância capital, no governo dos povos livres, é a temporariedade das funções eletivas. A perpetuidade do poder nas mãos de alguns homens termina por confundir o interesse nacional com o interesse destes homens. Os déspotas querem o poder vitalício e sem partilhas. Para não o perder, não vacilam, dispondo, como dispõem, do tesouro e da força, em suprimir a liberdade ao povo, em nome 
da disciplina, em lhe sacrificar sem entranhas o bem estar, e, mesmo, em lhe pôr sem clemência a vida a prego. E o povo, sem armas e sem dinheiro, que ha de fazer, nesta conjuntura, senão gemer, na humildade, a sua desdita, e clamar, morrendo, ave Cesar? Só quando lhe pareça propício, rebela-se de armas em punho, para se fazer ouvido e respeitado. Com a temporariedade do poder, porém, as eleições gerais resolvem satisfatoriamente, nos estados bem organizados, as crises mais graves.

O mecanismo da temporariedade não tem sido o mesmo em toda parte. O princípio é não admitir representantes políticos vitalícios. Mas, embora temporários, póde acontecer que, sem sair das suas atribuições, deliberem, em certos casos, contra as aspirações populares. Para evitar este abuso, duas técnicas têm sido empregadas pelos povos mais cultos: a técnica parlamentar, e a técnica presidencial. Na parlamentar, além da temporariedade do poder eletivo, se processa a dissolução da câmara dos deputados. 0 presidente da república, ou o rei, por si só, ou com assentimento da câmara alta, convencido do desacordo entre a opinião dos representantes e a opinião pública que os elegeu, dissolve a câmara e, no mesmo passo, convoca o povo para as eleições gerais. Já no regime presidencial, a dissolução das câmaras não tem logar. Neste regime, só resta o recurso de abreviar o mandato. Não apenas, temporário, mas breve. Dois anos são, nos Estados Unidos, a duração do mandato dos deputados. Eleições repetidas e a breve tempo previnem ou, pelc menos, reduzem a pouco o dissídio entre os representantes e os representados.

Terceira providência de igual monta é a limitação do poder. Não basta distribuir por três órgãos, sem vitalicidade, o exercício da soberania. $\mathrm{E}$ ' indispensavel precisar as atribuições de cada órgão do poder. E esta delimitação precisa não se alcança, sem determinar, cơn a fixação das competências, o que não podem fazer. Não é prudente traçar apenas a alçada de cada órgão do poder. E' absolutamente 
necessário delimitar o terreno sagrado dos direitos fundamentais, invioláveis pelos órgãos do poder. Sem esta limitação, a soberania seria praticamente o arbítrio dos representantes. E os órgãos do poder, embora menos que a multidão, não só erram de boa fé e por ignorância, senão tambem exorbitam por egoismo insofreavel, e política exaltada. A soberania só tem senso, quando poder de todos para o bem de todos. E o máximo dos bens que a todos interessa, é o respeito aos direitos fundamentais, como o da vida, o da igualdade, o da liberdade de pensamento, a liberdade de crença, de reunião, de profissão, de associação, de ir e vir, o poder de fazer, ou deixar de fazer, tudo o que, facultado a todos, não destrua a sociedade, nem lhe embarace o engrandecimento. Ora, para evitar abusos, possíveis, ainda no regime da tríplice organização de poderes temporários, a experiência tem sugerido, com a distribuição deles por três órgãos, já temporários, a definição dos direitos fundamentais do homem, como zona inviolavel pelo poder, instituindo, ao mesmo tempo, garantias que tornam efetiva essa inviolabilidade.

E' verdade que alguns povos, como o inglês, não limitaram os poderes de seu parlamento. Aí, os representantes deliberam sem nenhuma restrição, soberanamente. Mas os abusos dos partidos políticos, no parlamento britânico, são quasi impossíveis, mercê das suas tradições liberais, mercê do prestígio da corôa cuja onipotência caiu, mercê de uma câmara de lordes já sem o direito de veto à vontade dos comuns, mercê de uma opinião pública, sempre vigilante, organizada em partidos tradicionais, e mercê de uma imprensa do mais alto quilate.

Outros povos, porém, como os Estados Unidos, não confiaram, só nos freios da opinião pública, a segurança dos direitos fundamentais, contra abusos do poder. Os Estados Unidos, como país de ontem, país de imigração, trabalhado por todas as raças, movimentado por todas as tradições, todas as religiões, todas as ideologias, ainda não teve tempo de caldear as correntes dos povos, que o formam, numa con- 
cência nacional, apurada pelos séculos, em uma opinião pública por assim dizer atávica, como na sua mãe pátria. Daí, a sabedoria de limitar em lei suprema a competência do parlamento e a ação do executivo. Não lei ordinária, que o parlamento pudesse revogar por outra lei ordinária. Mas lei constitucional, que, só por outra lei constitucional, pudesse ser revogada. Enquanto, na Inglaterra, vigora sem restrições o princípio de que a lei posterior revoga as anteriores em contrário, nos Estados Unidos, como nos paises de constituições rigidas, as leis posteriores ordinárias não revogam as leis constitucionais, que lhes forem contrárias, criando-se, dest'arte, o problema de inconstitucionalidade das leis, a sua inaplicabilidade pelos tribunais, a sua nulidade prática.

Dá, em quarto lugar, em complemento à limitação dos poderes pelas constituições escritas, a competência da justiça para julgar em última instância da constitucionalidade das leis ou resoluções dos outros poderes.

O regime da supremacia do poder judiciário, como cúpula da constituição em garantia dos direito individuais, foi uma inspiração divina na organização do estado. $E^{\prime}$ o maior segredo da estabilidade nas instituições políticas dos Estados Unidos.

A Espanha, apesar da experiência americana de poderes independentes e harmônicos, caiu no erro de facultar ao parlamento a exoneração, por interesses partidários, do presidente da República, como, no regime parlamentar, a queda dos gabinetes. Precipitou-se, com a prática imponderada desta prerrogativa fatal no abismo da guerra civil, sem piedade, que a reduziu a escombros. Os Estados Unidos, ao contrário, firmaram, no aparelhamento do seu estado, a eletividade e temporariedade das funções de governo, a divisão, a independência e harmonia dos poderes, a limitação constitucional na competência de todos, e, para coroar este maravilhoso mecanismo, alçaram, em graça dos deuses, como guarda e oráculo da sua constituição, uma côrte de justiça que é garantia suprema da ordem jurídica. 
Constituição, aliás, de aspecto rude, mas armada de princípios que a lei ordinária não póde violar. De princípios que maiorias eventuais no parlamento não podem quebrar. Destes princípios, ressalta, como peça por excelência de segurança jurídica, a irrevogabilidade das leis constitucionais por leis ordinárias, e consequente aplicação pelos tribunais das leis constitucionais aos casos concretos contra as ordinárias que as contravierem.

Esta irrevogabilidade é o elemento específico do regime das constituições rígidas. Não é nunca prudente colocar os direitos do homem à mercê das paixões que convulsionem as assembléias políticas. Seria, sob a aparência de um regime de constituição escrita, instituir, na realidade, a identificação da soberania com a vontade das maiorias políticas ou a vontade pessoal do chefe do executivo.

Por isto mesmo, não é prudente arquitetar constituições analíticas, nem meter a martelo, no organismo de uma constituição escrita, preceitos de direito privado. As constituições que duram, são concisas, imperativas e só alteráveis, nalguns pontos, de século em século. 0 povo a deve ter na memória e no coração, como bíblia sagrada. Jamais revogálas no todo, para redigir outra. Mas, sempre, conservá-la, aperfeiçoando-a, até se aproximar da imutabilidade. 


\section{NATUREZA DAS LEIS CONSTITUCIO. NAIS. SISTEMAS DE CONSTITUI. ÇÃO. CONCEITO DO DIREITO CONSTITUCIONAL.}

São leis constitucionais todas as que se referem à estrutura e ao funcionamento do estado, e nada mais.

O estado pode ser unitário ou federativo, e é a lei que o determina. $\mathrm{O}$ estado pode ser republicano ou monárquico, é a lei que o institue. Como organização da soberania, póde o estado ter um só órgão supremo, ou dois, ou três independentes e coordenados, por onde se exerça a soberania, e é a lei que o estabelece. O estado póde funcionar sob o regime parlamentar, como sob o regime presidencial, e é a lei que o adopta. Todas as leis sobre a estrutura do estado são leis constitucionais.

Plasmada a corporação do estado, sob este ou aquele molde, ainda é a lei que distribue pelos seus órgãos as funções da soberania. Discrimina o que compete à união, aos estados ou provincias e aos municipios. Determina o que compete ao parlamento, com uma ou duas casas, e o que a cada uma incumbe; o que cabe ao poder executivo, e ao poder judiciário. E todas estas leis são leis constitucionais.

Como complemento deste segundo grupo de leis, além das que modelam a estrutura anatômica do estado, ha um terceiro grupo de leis que precisam as funções dos poderes. São as que levantam balisas ao arbítrio dos governantes. Não basta realmente declarar o que podem êles fazer; não 
menos importante é fixar o que não podem fazer, no terreno da personalidade do cidadão, e dignidade da vida humana. Embora escolhidos pelo povo, embora recebam do povo instruções para o governo, embora responsabilizados no tribunal da opinião pública, ou em tribunais especiais, que a lei institua, ainda é comum abusarem os governantes do poder em que se achem, contra a liberdade ou direitos compativeis com a coexistência próspera de todos. Ficam eles, e sobre todos o chefe da nação, armados da força militar, aparelhados dos recurses do tesouro, dispondo dos cargos públicos, aureolados de um prestígio irresistível, e o povo que os elege, que os arma, que para eles trabalha, fica inerme, desarmado de força militar, ou de outra qualquer que os possa conter dentro dos seus deveres de mandatários. Si os governantes agirem, por ambição pessoal, contra o povo que os elegeu, (e sabe-se que é proverbial rebelar-se a criatura contra o criador), não tem o povo como defender-se da traição com que o surpreendam.

O recurso extremo da conspiração que trame, o da revolução que deflague, é como o das operações cirúrgicas, quando não ha outro remédio, para recobrar a saude, ou evitar a morte. O que a inteligência elementar, a que prevê e sabe prover, está indicando, é evitar a necessidade das revoluções, cerceando, sem prejuizo de uma autoridade forte, os poderes aos governantes. Outorgue-se-lhe o que fôr necessário, sem regatear. Mas negue-se-lhe o desnecessário, seja como fôr. Delegue o povo aos seus representantes somente o que não puder fazer por si mesmo, como assinalara o avisado Montesquieu.

Já se distribuiram os poderes por três órgãos. Já se discriminaram as atribuições a cada um dos órgãos do governo. Mas é pouco. E' preciso opor expressamente a cada um deles barreiras intransponíveis, determinando em lei, além do que podem fazer, igualmente, em termos peremptórios, o que não podem fazer na seara dos direitos do homem. E o que 
não podem fazer, é tudo o que violar a razão de ser da soberania, tudo o que atentar contra o direito de viver, o direito de pensar livremente, o direito de ir e vir, o direito de associar-se, o direito de possuir, o direito de trabalhar, o direito de crer, o direito ao apôio da lei que defenda, o direito de eleger governantes, e outros da mesma natureza. A sociedade se fórma, para que possa o homem melhor viver e prosperar, e não para asfixiá-lo numa atmosfera sem ar. As leis que declaram quais sejam estes direitos, e, ao mesmo tempo, estabeleçam os instrumentos com que se fazem respeitados contra abusos do poder, são leis constituintes do estado, leis que definem a natureza essencial da soberania.

São, em suma, leis constitucionais: $10^{\circ}$ ) as que talham a estrutura do estado; $2 .^{\circ}$ ) as que determinam as competências dos poderes; e $3 .^{\circ}$ ) as que definem os direitos fundamentais do homem, e instituem garantias a estes direitos.

$\mathrm{Na}$ Inglaterra, as leis constitucionais vêm sendo elaboradas em fragmentos, de época em época, como imperativos da necessidade, a que tem provido em reações triunfantes. Mas, ainda hoje, são leis esparsas, não codificadas, costumes por onde a estrutura e as funções do estado se revelam. Nada ha, no direito constitucional inglês, que não tenha primeiro estado na conciência do povo, e não tenha sido por ela imposto como imprescindivel ao equilíbrio entre as liberdades populares e a autoridade pública.

Em outros paises, as leis constitucionais têm sido codificadas, como as civis, as penais, as comerciais. Em vez de usos e costumes, preceitos escritos, normas sistematizadas e distribuidas em livros, títulos, capítulos, secções, artigos e parágrafos.

Às vezes, antecipando à conciência jurídica do povo, a codificação constitucional é obra de arte literária, uma arquitetura romântica em nome e prol de uma ideologia, ou aspiração sonhadora. O povo não a sente, mal a conhece, ou a desconhece de todo. Não é o fruto que tenha desabrochado da seiva de sua vida. E' a of erta de um padrão ideal, 
por onde, se quizesse, poderia cunhar, pouco a pouco, a sua política. Com tal orientação, não é raro contravirem os costumes partidários ás leis constitucionais. Póde, neste caso, ter um povo, no papel, a mais bela constituição do mundo, e carecer, na prática, de segurança da vida, da liberdade e da propriedade.

Para codificação das leis constitucionais, não têm todos os povos adotado o mesmo sistema. Mas duas orientações.

A primeira consiste em não se distingüirem as leis constitucionais senão pelo seu objeto. São elaboradas como as leis comuns. São revogáveis como as leis ordinárias. Leis constitucionais e leis não constitucionais estão no mesmo nivel de gênese e de obrigatoriedade, têm o mesmo valor de aplicação. Não podem os tribunais, neste regime de nivelamento das leis, questionar sobre a constitucionalidade delas. Desde que votadas pelo parlamento, todas se impóem com igual força. E vigora, em toda a sua plenitude, o princípio de que as leis posteriores revogam as disposições anteriores em contrário. E' o sistema da Inglaterra e da França.

A conseqüência do nivelamento das leis, quanto à sua força imperativa, é a onipotência do parlamento. O parlamento só deixa, neste regime, de ser soberano, quando, par a par, se pratica o referendo popular e a iniciativa popular, um e outro irrestritos, e, em matéria constitucional, obrigatório pelo menos o referendo. Neste caso, a soberania, a palavra última, suprema, cabe sempre diretamente aos cidadãos ativos. Mas, sem a concomitância do governo direto com o representativo, o parlamento, sempre que se nivelem, na mesma força imperativa, as leis constitucionais e as leis ordinárias, é soberano, delibera o que entenda e como entenda, exerce, em suma, poderes ilimitados.

O segundo sistema consiste em se distingüirem as leis constitucionais das outras, além de pelo seu objeto, pelo processo da sua elaboração. Este processo é mais complicado que o da elaboração das leis ordinárias. Exige-se, para se 
instituirem leis constitucionais, maior número de proponentes, votação mais cerrada, maior número delas, e mais tempo para serem aprovadas. Fm alguns casos, como na federação, pode-se exigir, ou se exige, a intervenção legislativa das províncias, dos cantões, dos estados membros. De qualquer fórma, o processo de elaboração das leis constitucionais é mais complicado que o das leis ordinárias. E, por esta razão, toda lei em cuja elaboração se observar o processo comum, é nula, se contravier à lei constitucional. E' o sístema dos Estados Unidos.

Deste desnivelamento das leis constitucionais e ordinárias, quanto ao processo de sua elaboração, e quanto à sua força imperativa, decorre em conseqüência a limitação de poderes do parlamento. O parlamento não póde, em lei ordinária, contrariar disposição constitucional. Não tem poderes para se contrapor às leis constitucionais, senão revogando-as pelo processo complexo da sua elaboração.

Outra conseqüência, repitamos, é a capacidade dos tribunais, para decretar a inaplicabilidade de leis ordinárias, contrárias à constituição. Enquanto não revogada por outra lei constitucional, as deliberações parlamentares que a contrariarem, são írritas e nenhumas. E' mercê desta faculdade judiciária, que as leis constitucionais servem a conter abusos dos representantes, para maior segurança das liberdades individuais.

Por isto mesmo que, neste segundo sistema, os poderes se limitam pela constituição, que é o instrumento por excelência do mandato político, o instrumento ende se exaram os poderes que o povo delega aos representantes, não se compreende a inserção, nas cartas constitucionais, senão de matéria estritamente constitucional. O que não disser respeito à estrutura do estado, às atribuições dos seus órgãos, e aos direitos fundamentais, que o governo não pode violar nem por meio de leis, deve ficar no nivel das leis revogáveis pelo processo ordinário da elaboração. 
Dir-se-á que certos preceitos devem figurar nas constituições, por serem fundamentais à vida social, como, por exemplo, a indissolubilidade matrimonial.

Admitamos que o sejam. Mas são muitos os preceitos desta natureza em todos os ramos de direito. $\mathbf{E}$ a ter de elevar à categoria de lei constitucional tudo o que for fundamental, e não dever, por isto, ficar exposto a revogações fáceis, as constituições teriam de ser enciclopédicas, compendiando quasi todo o direito positivo.

Objetar-se-á que certos preceitos, como a indissolubilidade matrimonial, estão na conciência do povo, e é o povo soberano que quer, na sua soberania, a constitucionalização de tais preceitos.

O argumento erraria o seu alvo. Si certo princípio é sustentado pela conciência nacional, e si é a conciência nacional que dita as leis, tal princípio seria mantido em toda a sua plenitude pela conciência nacional, mesmo na situação de direito comum.

A razão sólida, a mais, por que se incluem, nas constituições rígidas, certos princípios, além da natureza constitucional imediata do seu objeto, é o amparo do homem, na sua vida e na sua liberdade, é a defesa de seus direitos fundamentais contra abusos do poder.

Alegar-se-á que é dificil verificar, entre os preceitos que limitam as atribuições dos poderes, os que importem na defesa direta da personalidade do homem, na garantia da liberdade contra abusos do poder. Parecerá a certos espíritos imbuidos de realismos e pragmatismo político, que esta verificação é pura metafísica, e, pois, assunto estranho à ciência do estado, e indigno da política.

No entanto, nada mais facil, nem mais necessário, que semelhante verificação.

Os princípios essenciais à vida juridica dos povos ou se acham expostos à violação sempre iminente do poder, ou não excitam, não assanham, não provocam nunca, na sua prática habitual, a má vontade, a cobiça, ou as iras dos governantes. 
Dos primeiros, citemos de exemplo a liberdade do pensamento. O seu exercício, no livre exame das cousas públicas, póde contrariar, e contraria de fato, a cada passo, os governantes. Dirigente nenhum recebe com agrado a oposição que lhe façam. E tal seja a situação, que eles não cochilariam, em defesa das suas posições, e até da sua tranquilidade, impedir o exercício da liberdade de pensamento. A liberdade de pensamento é um princípio contra cujo exercício o poder está sempre de pé atrás. Não ha nada mais exposto às violações por abusos de poder.

O mesmo não acontece com outros princípios, como a indissolubilidade do vínculo conjugal, ou a pontualidade dos pagamentos nas relações de crédito. A vigência da indissolubilidade matrimonial por toda a parte não irrita os governantes, não lhes abala a estabilidade, não os põe em perigo, não os incomoda com responsabilidades. A pontualidade dos pagamentos muito menos. Devem estes princípios, só por serem fundamentais à vida civil ou comercial, ser guindados às alturas de princípios constitucionais?

Para que? E porque, si, não resultando da paz doméstica, ou do hábito da pontualidade, ameaças ao poder, nunca sugerem tais princípios ao governo, para a sua tranquilidade, medidas que atentem contra o seu exercício?

Não assim o da liberdade da imprensa, ou de reunião em praça pública.

E não menos o princípio da propriedade: o espetáculo das riquezas alheias incita às vezes ao apropriamento sem indenização, sob a doutrina de que o capital está ao serviço do estado, e não o estado ao serviço dele: O poder é, muitas vezes, tentado, mesmo sob a fórma de defesa do estado, a desrespeitar a propriedade, com a decretação de impostos que confiscam, ou intervenções ruinosas na economia nacional.

Para que o poder não viole este e outros princípios juridicos, é que se definem eles nas constituições, e nelas se instituem os instrumentos da sua garantia, como o habeas- 
corpus. Ficam nestas alturas, como barreiras opostas ao exercício abusivo do poder.

Em suma, são leis constitucionais apenas as que modelam o estado, as que estabelecem as atribuições dos poderes, e as que definem os princípios expostos às violações pela autoridade pública. Direito constitucional é o conjuncto das leis que têm por objeto a estrutura do estado, a competência dos poderes e os direitos fundamentais cujo exercício póde suscitar reações dos governantes. 


\section{III}

\section{SEPARAÇÃO DOS PODERES, E DIS- TRIBUIÇÃO DE FUNÇõES. SUA EVOLUÇÃO. SISTEMAS ATUAIS. CONFLITOS E EQUILfBRIO.}

E' muito comum baralhar-se separação de poderes com distribuição de funções, ou divisão e colaboração dos órgãos de soberania. Reina, por estes lados, lamentavel imprecisão sobre o que seja realmente poder, função, autoridade pública, e órgão político. Desta confusão, por vezes mais verbal que real, resultaram controvérsias, não raro infantis, mas intermináveis e perturbadoras. No entanto, uma coisa é separação de poderes, e outra, muito diversa, distribuição de funções. E' o que examinaremos daqui a pouco.

Em sociedades incipientes, não se separam os poderes, e, até, a princípio, mal se discriminam as funções públicas e particulares. E' o que se observa facilmente nos pequenos agrupamentos de famílias, nas tribus rudimentares, semelhantes a certos aldeiamentos de índios, onde o cacique exerce o poder sem restrições, nem partilhas. Ele dá ordens, e as faz cumprir. Ele dirime litigios individuais, e julga os delitos, administra os interesses coletivos, e comanda nas guerras. Em suma, em tribus selvagens, como nos absolutismos à Luiz XIV, o estado é o cacique.

Mas assim que a tribu cresce e se desenvolve, já não pode o chefe resolver, por si só, todos os problemas da comunidade. Quando não haja outros motivos, faltam-lhe tempo, capacidade e resistência. Chama, então, como auxi- 
liares de seu braço, indivíduos de sua confiança com quem vai distribuindo as funções públicas. Estes auxiliares de que se cerca, porém, nada deliberam sem as suas instruções; não têm poder próprio; agem em nome do chefe. Comete este a uns o encargo de resolver querelas individuais, são os juizes. A outros ouve como conselheiros, ou incumbe a arrecadação dos impostos, ministros da fazenda, a organização das milícias, ministros da guerra, e assim para os demais serviços do estado. As funções públicas se distribuem, segundo as suas especializações, por indivíduos ou corporações, secretarias, assembléias, tribunais.

Mas todos os funcionários públicos, espalhados pelo país, são meros auxiliares do chefe. O chefe é o soberano, a cuja vontade todos obedecem sem tugir nem mugir. Do alto do seu trono, pode chegar à maravilha de forjar todos os moldes da vida social, desde a política até as modas, projetando a sua sombra, dia e noite, por toda parte, entre os empregadores e os empregados para contratar o trabalho, entre o produtor e o consumidor para tabelar o preço, entre páis e filhos para dirigir a educação, entre o crente e o sacerdote para pontificar a fé, entre o cientista e o público para dogmatizar a verdade, entre o homem e a mulher para disciplinar o amor, entre tudo e todos para que a nação seja um só pensamento e uma só vontade, ocupe o seu lugar no sól, e realize, na paz e na guerra, os seus destinos históricos irrenunciáveis.

Em tais povos, ha, sem duvida, distribuição de funções públicas: ministros que administram, câmaras que legislam, tribunais que julgam, e, para tudo, repartição onde se aglomeram funcionários de todas as categorias. Distribuição de funções, não ha duvida; mas não, separação de poderes. A distribuição pode, mesmo, ter atingido o grau máximo da perfeição. Da homogenidade inicial numa tribu primitiva, se pode ir ter a heterogeneidade complexa de funções nos estados modernos. Mas hierarquizados todas à vontade de um chefe. E' a caracteristica das sociedades incipientes, 
encruadas, ou retrogradadas: distribuição de funções, mas não separação de poderes.

Esta começou, na história dos povos, com as reivindicações liberais.

Percebe facilmente o povo que a absorpção de todos os poderes por uma só vontade termina por lhe semear a desgraça nos caminhos da vida. As vantagens apregoadas da ordem e disciplina lhe custam, na verdade, os olhos da cara. E, de outro lado, as desvantagens da concentração dos poderes, sem audiência dos governados, reduzem o povo a manadas de alimárias, que se sacrificam em combustíveis de guerra, para forjar a glória dos ditadores. E' lição da história: por toda parte, em todos os tempos, o absolutismo estiolou em germens a capacidade adquirivel de se governar o povo por si mesmo.

Mas, como, no homem, ainda o mais desgraçado, sob as cinzas de sua degradação, não se apagam os últimos vestígios da centelha divina, que lhe vem da origem, só se conforma a criatura humana com a sujeição que a deprima, quando e enquanto não puder reagir. Os povos mais virís foram atacando o poder ilimitado dos reis, e reclamando para si uma participação cada vez maior na estatuição das leis. De reivindicação em reivindicação, terminaram alguns povos, como, em primeira plana, o povo inglês, por conferir a si mesmos todo o poder de legislar. Durante muito tempo, ainda ficaram os reis com o poder de executar as resoluções que o povo estatuia. Mas, como no exercício desta prerogativa, os monarcas solapassem, às vezes pela astúcia, e outras pela força, o privilégio de legislar que o povo lhes subtraíra, as reivindicações populares foram às últimas, chamando o povo tambem a si a função de executar as leis e resoluções que votasse. Aqui, destronando monarcas como na França de Luiz XVI; ali, conservando-os como na Iglaterra, onde reinam, sem governar.

Quebrada assim a hierarquização de todas as funções soberanas ao arbítrio de um só homem, estava, no mesmo 
passo, lançada a separação verdadeira de poderes, como sistema distinto da simples distribuição de funções.

Nem pelas causas que as geram, se pode confundir distribuição de funções com separação de poderes. Uma, a razão por que se separam; e outra, a por que se distribuem.

Distribuem-se as funções públicas segundo as suas espécies, para que sejam exercidas com menor dispêndio de forças e maior eficiência prática, com menos desacertos nas deliberações, e mais a tempo e a hora na aplicação.

Separam-se os poderes, para melhor garantia da liberdade.

Pode haver função sem poder, e nunca poder sem função.

Função é a faculdade e o ato de agir dentro das leis ordinárias.

Poder é, além de função, a faculdade de agir por delegação direta da soberania. Não, faculdade soberana de agir, nem, como se exprimia Robespierre, "as diversas partes essenciais e constitutivas da soberania" Poder não é a soberania em si. Mas delegação direta da soberania. Enquanto os órgãos forem apenas de funções, a hierarquização entre eles é condição de sua eficiência, e, até, de sua subsistência. Mas quando se alçam a poderes, a hierarquização desaparece, é possivel opor-se uns aos outros; são independentes entre si, embora devam ser harmônicos e em mútua colaboração.

Enquanto apenas função, não ha garantia da liberdade. Só quando poderes, a garantia surge contra os excessos do executivo.

$\mathrm{Si}$, em cada sociedade, os indivíduos não se molestassem entre si, si só fizessem ou deixassem de fazer o que, generalizado, não destruisse a sociedade, nem lhe embaraçasse o desenvolvimento, claro está que não precisaria haver autoridade pública, governo de qualquer espécie. Mas, como, por incapacidade, por ignorância e por ambição, os 
homens, na mesma sociedade, se entrechocam, quando largados a si mesmos, força é que se institua, em cada sociedade, o poder público, com o encargo de obrigar a cada um o respeito às condições de vida e prosperidade do todo.

Mas, por outro lado, porque o poder público é exercido, afinal, por homens, e estes, tambem por incapacidade, por ignorância e por ambição, em vez de o exercerem somente em benefício das condições da vida e prosperidade do todo, costumam transviar-se, praticando atos contra a liberdade e contra os interesses gerais, a dura experiência da vida tem levado os povos sensatos a já não confiar às cegas o poder público, que são obrigados a instituir, ou suportar, a não confiá-lo ao arbítrio de um só homem. Além da cuidadosa distribuição das funções, que já tenham, sentem-se os povos na indeclinavel necessidade de opor ao poder executivo o poder legislativo, e, às vezes, a um e ao outro, o poder judiciário.

Em lógica abstrata, parece que só ha logar para dois órgãos do poder: o que faz a lei, e o que a executa. Correspondem, dizem, aos dois momentos essenciais na vida da lei: o ato que a cria, e o ato que a realiza. Os poderes seriam, então, dois: o deliberativo e o executivo. 0 primeiro resolveria os negócios do estado, e o segundo executaria as deliberações do primeiro.

Nessa teoria, as funções judiciárias ficam entre as do executivo. São realmente aplicação da lei. Desde que alguém alegue a existência de um atentado ao direito, o poder público verifica, pelos seus agentes, a procedência ou não do alegado, e resolve, com as provas que colher, a questão de direito suscitada. Resolve assim declarando o direito, o conteúdo da lei, como providenciando a execução da sentença que lavrar. "Para que haja um ato jurisdicional, expõe com insistência Duguit, é preciso que haja uma questão de direito a resolver; é preciso que se tenha suscitado esta questão de direito, e é preciso que o agente público intervenha antes do mais para resolver esta questão de direito. E' sobre isto que releva insistir particular- 
mente, porque é o que carateriza propriamente o ato jurisdicional".

As soluções jurisdicionais se impõem de si mesmas; têm de ser acatadas, respeitadas, cumpridas. A função judiciária não termina com a solução dada à questão de direito que tenha sido submetida ao juiz. Continúa nas medidas que tenham por escôpo fazer respeitada e cumprida a solução que o juiz tenha dado. Sendo esta a natureza das funções judiciárias, e si só nisto ficasse, realmente a autoridade judiciária não se poderia razoavelmente destacar das funções executivas.

Não é, porém, universal a teoria de dois órgãos apenas do poder, e, pois, de que o judiciário não é poder. Nos Estados-Unidos são três os órgãos da soberania, o legislativo, o executivo, e o judiciário, como o eram entre nós, até a constituição de 1937.

Dois são os sistemas de separação de poderes. O sistema parlamentar, que a Inglaterra, a França e outros povos adotam, cada um com as suas pequenas diferenças locais, e o sistema presidencial que os Estados-Unidos implantaram em 1787, e que se irradiou pelo continente americano.

O sistema parlamentar é o da dicotomia do poder. O sistema presidencial é o da tricotomia.

Não se trata, aqui, de uma questão opinativa. Mas de realidades objetivas. No sistema parlamentar não se póde deixar de reconhecer a supremacia da câmara legislativa sôbre os demais órgãos da autoridade pública. No sistema presidencial, porém, o executivo e o judiciário são poderes como o legislativo.

E' que nos Estados-Unidos, as decisões da justiça se impõem ao legislativo e ao governo, contendo-os, a ambos, nas ráias inconfundíveis das suas atribuições constitucionais. O judiciário póde opor-se ao poder legislativo como ao executivo. $O$ que eleva a função judiciária à categoria de poder, não é apenas o fato de intervir o juiz para resolver uma questão de direito, e fazê-la vingar. Mas a prerroga- 
tiva nova de se opor ao poder executivo nas suas ilegalidades contra a ordem jurídica, e, cousa realmente nova, opor-se igualmente ao legislativo nas suas deliberações inconstitucionais. Enquanto não puder opor-se a outro poder é apenas autoridade judiciária, pura e simples. Mas si as suas decisões tornarem nulas resoluções do legislativo por contravirem a constituição, então, mais do que autoridade judiciária, é poder judiciário. Está no mesmo nivel que os demais poderes. Exerce, no seu sector, autoridade suprema, delegada embora, mas suprema. E é por isto que póde opor-se ao poder legislativo e executivo nas suas demasias.

Poder aqui significa a competência que se tenha, de agir sem subordinação ou revisão de outro poder, embora em cooperação com ele, e por delegação direta do povo soberano. A delegação do exercício da soberania, em dada esfera, se expressa em constituição rígida, e não apenas flexivel. O elemento específico do poder, como potência acima de autoridade, ou mero órgão de funções específicas, é a capacidade de opor-se a qualquer poder. Nos EstadosUnidos, uma decisão da Suprema Côrte põe embargos a deliberações dos outros poderes, por contrários a preceitos da constituição de 1787.

$\mathrm{Na}$ Inglaterra, não. As deliberações de seu Parlamento são soberanas. Não ha, na Inglaterra, constituição rígida, que limite os poderes da Câmara dos Comuns. O executivo é mera delegação do Parlamento sob a forma de gabinete ou ministério. E o judiciário não pode deixar de aplicar uma lei do Parlamento, sob o pretêsto de sua inconstitucionalidade. A inconstitucionalidade das leis não é problema que se suscite nos tribunais ingleses. Por isto, em rigor, o que ha, na Inglaterra, é uma divisão de funções, cooperação do executivo com o legislativo, e supremacia final do Parlamento.

Com pouca diferença, na França. Lá, o judiciário não é realmente um poder, mas uma autoridade pública. "Chegou o momento, confessa Hauriou, de declarar francamente que o regime democrático exclue o poder judiciário da lista 
dos poderes públicos empenhados no jogo político da separação dos poderes"

"Mas, acrescenta, deve ele ser substituido por outro que é o poder de sufrágio. - Gradualmente, com os progressos da soberania nacional e do sufrágio, o poder do sufrágio tem participado mais ou menos do govêrno com o poder executivo e com o poder deliberante" A multiplicidade e a periodicidade das eleições importam numa participação direta do povo no equilíbrio dos poderes.

De modo que, para Hauriou, ha, na França, três poderes: o legislativo, o executivo e o de sufrágio. $O$ judiciário é ramo do executivo.

Não nos parece acertada a inclusão do poder de sufrágio entre os poderes do estado. Trata-se de uma democracia representativa. E, dentro dela, o sufrágio não decide, mas renova a representação, para que ela renovada decida.

$\mathrm{Na}$ França de 1789, a Assembléia nacional distinguia três poderes, um dos quais era o judiciário, independente e igual aos dois outros. Pela declaração de 1789, art. 16, e pela constituição de 1791, os poderes eram partes essenciais e constitutivas da soberania. Sonharam os revolucionários criar três poderes, e, particularmente, um legislativo e um executivo absolutamente independentes entre si. A constituição de 1848 , art. 19, insiste nos princípios do romantismo revolucionário de 89. "A separação de poderes, proclamara ela, é a primeira condição de um govêrno livre".

Mas o erro de uma separação absoluta de poderes, cada um dos quais agindo soberanamente em órbita própria, se tornou manifesto nos golpes de estado que geraram os absolutismos napoleônicos. "Os fatos políticos, doutrina Duguit, são o produto de uma infinidade de causas complexas. Mas estou convencido que a separação rigorosa que se pretendeu estabelecer entre os órgãos, no ano III, e em 1848, foi a causa principal dos graves conflitos que acabaram em golpes de fôrça" 
A lição aproveitou aos francezes. E, hoje, na França, outra é a concepção jurídica de separação dos poderes. "O que se chama hoje separação dos poderes, continua Duguit, (D. C., V. II, pg. 536) é uma regra em virtude da qual existem órgãos de representação de soberania nacional, uma colaboração íntima e constante destes órgãos, uma ação recíproca de uns sôbre os outros, e tambem uma separação entre o pessoal administrativo e o pessoal judiciário, uma independência tanto quanto possivel atribuida ao pessoal judiciário"

Quer dizer que, rigorosamente, não ha, na França, separação de poderes. O parlamento e o govêrno, encarnado no chefe do estado, exercem um sôbre o outro uma ação recíproca constante, pondo em comum seus esforços para a realização dos fins do estado. O sistema de hoje é bem diverso, nota Duguit, do que se quis estabelecer em 1791, em que cada um dos órgãos incorporava um elemento distinto da soberania, e devia ser independente e soberano em sua esfera.

E pondera: "Eu creio que, para evitar confusão, em logar de separação de poderes, melhor seria dizer colaboração dos órgãos"

O judiciário, tambem para Duguit, não é um poder. "Para demonstrar que a justiça é um poder autônomo, seria preciso demonstrar que ela é um elemento destacado da soberania do estado, incorporada em um órgão de representação. Ora, essa demonstração é impossível, porque este fracionamento da soberania é impossivel. E' uma concepção metafísica, sem valor real"

Em suma, "o que se chama impropriamente separação de poderes é a diversidade de participação dos diferentes órgãos na atividade geral do Estado" (Op. cit. pg. 341)

Realmente, a separação de poderes não póde ser concebida, hoje, como a coexistência de dois ou mais órgãos soberanos em sua esfera de ação. Cada qual giraria à parte, sem contato com os outros. E como a finalidade do estado é uma só, estes órgãos independentes inevitavel é 
que terminem por se hostilizar, e gerar os golpes de estado. Modernamente, separação de poderes corresponde a duas realidades diferentes.

Ora, é a repartição das funções do estado por dois órgãos, em cooperação recíproca, mas subordinado o executivo à onipotência do parlamento; ora, é a repartição de funções por três órgãos independentes e coordenados entre si. Aquela é o sistema parlamentar. Esta, o presidencial.

No sistema presidencial a separação de poderes compreende, além da repartição de funções, a independência entre os órgãos, sem quebra da harmonia e cooperação com que devem agir, para a realização dos fins do estado. No sistema parlamentar, o poder executivo se subordina à soberania do parlamento. No presidencial, não. Os poderes são três, e ha, entre eles, independência e harmonia.

Não divaguemos. Independência dos poderes é essencialmente:

Primeiro, não serem nunca os órgãos de poder confiados às mesmas pessôas. Quem exerce função de um está privado de exercer as de qualquer outro.

Segundo, não ter nenhum dos órgãos o arbítrio de compor ou exonerar membros dos outros órgãos. Compreendese que, já na composição geral dos órgãos, já na dissolução coletiva do parlamento, já na exclusão de alguns membros de qualquer esfera, intervenham os demais órgãos. Mas sem arbítrios, sem poderes discricionários, senão como aplicação rigorosa da lei. E' o que se verifica, por exemplo, quando o parlamento destitue por crime de responsabilidade o presidente da República; quando o poder judiciário sentenceia à perda do mandato, por infração à lei, a um parlamentar; ou quando o chefe da nação, com apôio do senado, nomeia, (onde não é eletiva a composição da magistratura) os ministros do Supremo Tribunal. Mas, em todos estes atos, nenhum poder tem o direito de demitir a seu alvedrio membros dos outros poderes; nenhum pode exonerá-los a nuto. E' possível admitir-se, mesmo, que só os membros de cada poder possam destituir seus pares do 
mandato que exerçam. Mas ainda quando se admita a interferência de uns nos outros, é sem arbitrios, em obediência rigorosa à lei. Pela mesma razão por que não é possivel que membros de um poder exonerem a seu salvo membros de outros poderes, não é admissivel que os prendam. A independência desapareceria sem as imunidades parlamentares ou judiciárias. Salvo caso de flagrante em crime inafiançavel, a prisão só póde efetuar-se, com prévia licença do órgão a que pertença o indigitado. Praticamente, a independência consiste, sob este aspecto, em não ficar membro nenhum de qualquer dos poderes à mercê do arbítrio de outro poder.

Terceiro, não poder nenhum órgão anular ou alterar as deliberações dos outros, em matéria de sua competência privativa. A competência de cada órgão é determinada pela constituição. As funções que se distribuem pelos órgãos da soberania, são de duas naturezas: $1^{\circ}$ ) competência privativa, como a do parlamento para emendar a constituição, a do judiciário para dirimir litígios entre indivíduos, e a do executivo para comandar fôrças armadas; e $20^{\circ}$ ) competência concomitante, como a do parlamento e do executivo para elaborarem uma lei ordinária, comporem a suprema Côrte, ou ultimarem tratados internacionais. A independência nas funções privativas não poderia, em bôa técnica, excluir a cooperação em funções comuns, e, mesmo, nas privativas. Como os interesses que eles disciplinam, são do estado, da pátria comum, do povo todo, a privatividade não exclue a harmonia com que todas agem para o predomínio da lei, e realização do bem geral. Nas competências privativas, porém, se acentua o traço mais vivo da independência.

Mas, além da independência entre os órgãos, como elemento que eleva as funções a poderes, um segundo elemento caracteriza a separação de poderes no sistema presidencial. Na concepção de que poderes são elementos intrinsecos da soberania, os órgãos que os exercem, giram em esferas autônomas, sem se tocarem teoricamente, mas, na prática, em hostilidades iminentes, que desfecham, como sig- 
no fatal, golpes de estado. Na concepção, porém, de que poder é a capacidade de agir, por si, sem dependências mas por delegação constitucional da soberania do povo, além da independência com que agem entre si os poderes, mercê das suas atribuições privativas, o executivo e o legislativo colaboram nas mesmas atividades públicas, e todos, mesmo nas competências exclusivas, se inspiram na mesma finalidade do estado. Daí, como segunda caracteristica da separação de poderes, a cooperação, a harmonia entre eles. Não só independentes, mas harmônicos ou coordenados.

Dir-se-á, talvez, que seria mais simples e mais harmônico a hierarquização de todos os poderes a um só órgão. Haveria, dentro do país, mais ordem e mais disciplina, e, nas relações externas, mais respeito ao direito e maior projeção internacional da nação.

Mas ha uma razão prática da maior importância para a separação dos poderes. E' a garantia da liberdade contra as tiranias e as demagogias. A liberdade política, assignala Montesquieu, no Espirito das leis, Livro XI, Cap. IV, não existe, ainda nos governos moderados, senão quando não se abusa do poder. "Mas é uma esperiência eterna que todo homem que tem o poder, é levado a dele abusar. Ele vae até onde encontre barreiras. Quem o diria? A própria virtude tem necessidades de limites. Para que não se possa abusar do poder, cumpre que, pela disposição das cousas, o poder detenha o poder."

Retrilhando o caminho desbravado por Locke, na observação dos costumes politicos da Inglaterra, Montesquieu acrescenta :

"Quando na mesma pessoa ou no mesmo corpo de magistrados, o poder legislativo se confunde com o executivo, não ha liberdade, porque é de temer que o mesmo monarca ou o mesmo senado faça leis tirânicas, para executá-las tiranicamente. Ainda não ha liberdade, si o poder judiciário não se separa do legislativo e do executivo. Si estivesse reunido ao legislativo, o poder sobre a vida e a liberdade dos cidadãos seria arbitrário, pois que o juiz se- 
ria o legislador. Si reunido ao executivo, o juiz teria a força de um opressor"

A grande lição que Montesquieu colhia da organização política da Inglaterra, é que só quando se oponha o poder do povo ao poder dos reis, tem o povo resguardada a sua liberdade contra a opressão dos reis.

Locke, antes de Montesquieu, já tinha posto em relevo a repartição de funções da Inglaterra. Eram, no seu entender, três os poderes: o legislativo, o executivo e o confederativo. No estado que tudo faça pela conservação da sociedade, doutrinava Locke, "não ha senão um poder supremo que é o legislativo, ao qual os demais devem estar subordinados."

Já não se trata de hierarquização dos poderes à vontade de um homem ou do executivo, mas à vontade do parlamento que representa o povo. $\mathrm{E}$, como, com a separação de poderes, o que se tem por mira é opor o povo um poder seu ao executivo que o tiranize, nada mais sábio que organizar o povo um poder seu que contenha a corôa no respeito às liberdades públicas. Mas conservou o povo inglês o poder executivo separado do legislativo. Porque, "si as pessoas que fizerem as leis tiverem o poder de executá-las, grande seria, dada a fragilidade humana, a tendência de acomodarem as leis aos seus interesses privados, e estes interesses podem ser contrários aos fins da sociedade e do governo. Onde o bem público for levado a sério, o poder que faz as leis, se separa do poder que as executa" (Essay of civil government).

Através das lutas constantes pela liberdade, o povo inglês obteve, na Câmara dos Comuns, que o representa, a soberania dos seus destinos políticos. Hierarquizando, embora, o executivo ao parlamento, e não admitindo, apesar do imenso respeito que vota à justiça, opor-se o poder judiciário às suas decisões soberanas, a liberdade ficou acautelada contra os abusos do governo. Não teria ficado, contra as demasias das multidões, contra as loucuras demagógicas, contra a vontade sem peias da plebe, si não fossem 
as suas tradições liberais, a consciencia civica e jurídica popularizada, como sangue vivo que circula oxigenado nas veias do país. E estas tradições de liberdade, esta cultura cívica e jurídica não se improvisam.

Os Estados-Unidos, apesar de sua origem britânica, das suas tendências britânicas, de seu propósito de imitar, quanto possivel, a organização política da mãe pátria, não tinham tradições que refreiassem os excessos às massas populares. Não é de confiar o exercício direto da soberania a um povo sem cultura profunda, e sem tradições jurídicas. A soberania não é onipotência para tudo. Tem uma razão genética de ser. Ela surge para assegurar as liberdades iguais. A opressão sempre nefasta não é só das corôas. E' mais grave ainda, quando concebida nas entranhas das turbas, nas sociedades populares de salvação pública, nas assembléias nacionais à 1789. Daí não terem os patriarcas da democracia americana adotado o sistema inglês de opor apenas ao executivo o poder legislativo. Era preciso acautelar-se contra os excessos das multidões no legislativo, as suas paixões, os seus baixos interesses, a sua decadência plebéia. Mas como? Definindo, numa constituição rígida, os princípios jurídicos, estáveis ou eternos, que limitem os poderes ao parlamento. Este não é soberano. Soberano é só o povo diretamente, ou representado em congresso constituinte.

Mas, para que tal constituição, limitadora dos poderes do legislador, como do executivo, não ficasse exposta aos golpes de estado de um e outro, os constituintes americanos alçaram à categoria de poder o órgão judiciário, para defender a constituição contra abusos do governo ou do parlamento, opondo-os, como poder, aos outros dois poderes nas suas resoluções inconstitucionais.

Daí o sistema americano da verdadeira separação de poderes independentes e coordenados entre si. Três são os órgãos de soberania nacional: o legislativo, o executivo é o judiciário, independentes e harmônicos entre si, como se exprimia, entre nós, a constituição de 1891. A de 1934 re- 
produziu o conceito. E a de 1937 abriu mão dele e do sistema, para hierarquizar todos os poderes ao chefe do executivo, em nome de misteriosas realidades brasileiras.

Mas que é o que se pode alegar contra o sistema presidencial de separação dos poderes?

Duas objeções andam no ar. Preliminarmente, alegase, a separação de poderes só existe na "teoria literária das constituições"

Isto seria verdade si a separação de poderes fosse o que apregoaram os revolucionários de 1789, ou 1848, na França.

Mas, objetam, a separação de poderes é incompativel com a soberania, por natureza indivisivel. E' o que dispara Duguit com esta energia:

"Sendo soberana a vontade geral, é soberano cada um dos elementos que a compõem; cada um destes elementos da soberania é delegado mediante representação a um órgão e cada órgão exerce uma função diferente. Finalmente um poder é um elemento fracionado da soberania incorporado em um órgão, o qual exerce uma função correspondente. Sendo indivisivel a soberania, cada um destes poderes é soberano, e sendo una a soberania, posto haja muitos poderes soberanos, não ha jamais senão uma só soberania"

Compara, então, Duguit, para causticar a doutrina com ferro em brasa:

"O espirito aproxima espontaneamente essa teoria da trindade politica com a teoria teológica da trindade divina. A mesma concepção e a mesma maneira de raciocinar são a base de uma e outra. A divindade é una $e$ indivisivel. Formam seus atributos outras pessoas distintas, igualmente divinas. Mas a divindade continua una e indivisivel, apesar da exịstência de três pessoas divinas. Da mesma fórma, a soberania é una e indivisivel, seus atributos formam três pessoas distintas igualmente soberanas. Não obstante, ha uma só soberania una e indivisivel, apesar da existencia de três poderes soberanos" (D. C., V 2, p. 522). 
A este aspecto, realmente, não ha teoria cuja metafísica páire mais acima das nuvens. Mas é critica à concepção franceza de 1791 e 1848. Nada tem que ver com a realidade da separação de poderes, como na vida constitucional dos Estados Unidos.

A soberania não pode deixar de ser, em cada povo, uma só; não se compreende a coexistếncia de duas ou mais. $E^{\prime}$ una e indivisivel.

A separação de poderes, na teoria e na prática americana, não implica em ser cada poder soberano. Nenhum é soberano. Só a nação é soberana. Para que cada poder, ou qualquer, fosse soberano, seria preciso que cada um pudesse agir sem subordinação a nenhuma vontade senão à sua, tivesse poder acima da qual não existisse outro. Ora, isto não se dá no sistema presidencial. O legislativo está subordinado à constituição. O executivo não pode transpor as ráias constitucionais. O judiciário só pode aplicar a lei sem legislar. Nenhum gosa de poderes ilimitados. A separação no sistema presidencial, é de poderes limitados. Se nenhum é soberano, como supor contradições entre a separação deles e a indivísibilidade da soberania? A contradição seria flagrante, si os poderes fossem parcelas soberanas da soberania nacional. Mas não é o que se apregoa em doutrina, nem o que se realiza no governo estadunidense. Cada poder é um orgão com a competência de agir, ora em cooperação, ora em independência recíproca, mas todos por delegação de soberania nacional, a cuja constituição estão sujeitos.

A segunda objeção é mais complicada.

Sabe-se, por experiência, que não podem duas ou mais pessoas mandar por último na mesma casa. Emquanto estejam de acordo, tudo vai bem. Mas, na hora da desinteligência, quem resolveria o dissídio? Si, surgido o desacordo, chegassem a uma composição amigavel, ainda tudo iria bem. Mas se tomar cada um atitude intransigente? Si terminar um por impor sua vontade, ficará só ele a mandar por último. Si não chegarem por si mesmos a nenhum acomodamento, nem houver imposição da vontade do mais forte, a 
discórdia perdurará, anarquizando tudo, escancarando as portas aos golpes de estado. Na hipótese de terminar por impor um sua vontade aos outros, some-se a coexistencia de po-

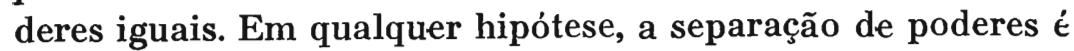
um devaneio de teóricos, sonho de juristas sem o senso real da vida. Em suma, o que, a este respeito, a experiência nos ensina, é que a separação de poderes é sempre nefasta. "Na Constituição do ano III, expõe Duguit, a Convenção reproduziu quasi nos mesmos termos os princípios de 1791 sobre a separação dos poderes e a regra dos três poderes. Ela tentou criar tambem três poderes e particularmente um poder legislativo e um poder executivo absolutamente distintos e independentes um do outro. Sabe-se quantos males resultaram disto. A história do governo ditatorial é a de uma série ininterrupta de golpes de estado; ela acabou no 18 brumário, que destruiu o regime" (D. C., Vol. 2, p. 533). A objeção é, pois, que a separação de poderes é a causa principal dos golpes de força, contra os regimes que a instituirem.

E' preciso, porém, distinguir. Si a separação de poderes é a de vários órgãos, rigorosamente independentes entre si, soberanos, sem colaboração recíproca, claro está que a conseqüência fatal é o não funcionamento do governo, e, por fim, os golpes militares, que subistituem a lei pelo arbítrio.

Mas si separação de poderes não é o sistema romântico da revolução franceza, mas o sistema parlamentar inglês, ou francês de hoje, ou o sistema presidencial dos EstadosUnidos e do fim da primeira República entre nós, a objeção já não procede.

Certo, os atritos podem surgir. Mas ha, para cada um deles, solução legal. A independência, sem soberania, não exclue a cooperação e harmonia entre os poderes. E' o que facilmente se póde verificar.

Mas respondamos à objeção. Assinalemos, em primeiro logar, que onde não houver separação de poderes, haverá hierarquização deles ao arbítrio do poder executivo, e, ás vezes, do legislativo. E, a conseqüência desta hierarquização 
é quasi sempre a tirania, a supressão da liberdade, e o opróbrio da vida.

Não se deve perder de vista que os fatos sociais são complexos, e, por vezes, contraditórios. Hoje, como outrora, se encontram os dois regimes: o da hierarquização e o da separação de poderes.

Que é o que se pode concluir desta realidade? Não se pode generalizar uma parcialidade. Só se infere em lei a unidade na variedade dos fenômenos. Onde não se trilhar unidade, não ha o que induzir.

Mas, por outro lado, a ciência não se constitue de fatos isolados. E' uma sistematização de leis. Não basta, na espécie vertente, notar a contradição dos fatos. Ha, em cada um deles, causas e efeitos?

Duas causas, pelo menos. A primeira é a hierarquização dos poderes. A segunda, a separação deles. São dois fatos de que defluem conseqüências diferentes. Poder-se-á determinar a constância e permanência entre aqueles antecedentes e estes conseqüentes?

Verificadas as relações constantes entre uns e outros, isto é, entre a hierarquização dos poderes, como antecedente, e os resultados que dela decorrem, como conseqüente, e, da mesma fórma, entre a separação de poderes, como antecedente, e os resultados que dela derivam, como conseqüentes, passa o observador a uma nova indagação. Entre estas e aquelas conseqüências, qual o grupo que corresponde aos fins da sociedade, ou á razão de ser do estado? A hierarquização ou subordinação de todos os poderes ao arbítrio de um homem é favoravel ou contrária à vida e desenvolvimento do indivíduo e da sociedade? A independência e harmonia dos poderes é favoravel ou contrária ao destino do homem e aos fins da sociedade?

O problema póde complicar-se. O homem e a sociedade são hoje o que não foram ontem, diferem aqui do que são acolá. De modo que as conseqüências da dependência ou da independência dos poderes entre si podem variar conforme 
a raça e a cultura do homem, conforme as tradições, as condições econômicas e situação de vízinhança e outras da so. ciedade. E o regime que hoje der certo, póde amanhã, com a mudança das circunstâncias, ser entrave à conservação e desenvolvimento do povo.

Considerados devidamente todos estes fatores, a ciência registrará as leis, isto é, as relações constantes entre os regimes em prática e os seus malefícios ou benefícios verificados.

Nesta verificação, um dos elementos de maior pêso na produção das conseqüências ou efeitos dos regimes em ação, é a natureza da vontade humana nos que governam. Não se póde, senão incidindo em erros irremissíveis, abrir mão da grande lei psicológica, posta em tanto relevo por Montesquieu, de que o poder tende sempre aos abusos, e só se detém deante do poder.

Tudo considerado, conclue-se que, na realidade dos fatos, em condições normais, isto é, num povo civilizado, exceptuadas as épocas em que se convulsione em anarquia, os resultados da independência e harmonia dos poderes entre si são mais favoráveis à conservação e desenvolvimento do homem e da sociedade, do que as conseqüências da hierarquização de todos os poderes ao arbítrio de um só homem, ou de uma corporação.

A razão é sempre a mesma: quem quer que disponha do poder, tende a abusar dele. Só se detém deante de barreiras que não possa remover. Só se eximiria desta lei quem estivesse em cheiro da santidade. Por mais patriota, por mais bem intencionado, por mais firmeza que tenha de caracter, não ha quem escape à contingência humana, mesmo em boa fé, do erro e do abuso.

Deante disto, o dilema de que a separação de poderes ou dá em anarquia e gera golpes de força, ou termina por ser substituido pela hierarquização, já perde os seus contatos com as realidades sociais.

Resta, então, examinar si realmente ha, ou não, no mecanismo da separação de poderes, soluções legais para os con- 
flitos entre eles. Si houver, o dilema cái. Si não houver, colhe.

Ora, três ordens de atritos são possíveis entre os órgãos de soberania.

Primeiro, reações entre o legislativo e o executivo.

Segundo, divergências entre o judiciário e o legislativo, agravadas, às vezes, pelo apoio do executivo ao legislativo.

$\mathrm{E}$, terceiro, choques entre o judiciário e o executivo.

Três são os poderes. Três as ordens de desencontros entre eles. Si houvesse um poder moderador, chave e cúpula do sistema, então a solução dos conflitos entre os outros três poderes caberia ao poder moderador. Mas teriamos, com ele, caido na hierarquização dos poderes a um só.

A hipótese é de não haver poder moderador, poder supremo, mas três órgãos da soberania nacional, independentes e harmônicos entre si. As desinteligências entre estes órgãos são inevitáveis. E de duas uma: ou ha solução legal para elas sem quebra da independência que essencializa a separação, ou não ha solução legal, e, na atmosfera e mal estar reinante, as desordens virão, virão os golpes de estado, que mudam regimes.

E' preciso, pois, para valer de fato o sistema de separação de poderes, resolverem-se, dentro da lei, os conflitos que surjam entre eles.

Nos paizes bem organizados, como os Estados-Unidos, as soluções existem apropriadas e imperativas, sem criação de um quarto poder, o moderador, e sem apelo a plebiscitos ou referendos.

Vejamos.

Primeiro, atritos entre o executivo e o legislativo.

Os desentendimentos entre eles podem ser de duas espécies: ou na estatuição das leis, ou na política do governo. Num e no outro caso, as soluções variam com o sistema parlamentar ou presidencial de separação de poderes.

No sistema parlamentar, as desinteligências mal chegam a esboçar-se, porque a separação de poderes é mínima, ou 
quasi só reduzida a uma separação de funções e cooperação recíproca, mas, afinal, sob a vontade soberana do parlamento. Já no regime presidencial, a separação de poderes é ampla, positiva, inequívoca, e, por isto, os conflitos são dia a dia iminentes. Já não estão os poderes sob a vigilância onipotente do parlamento, ou de outro órgão, e, por isto, serão não apenas iminentes, mas da maior gravidade, os conflitos dos poderes, si não houver, no sistema, instrumentos que lhe permitam o funcionamento em harmonia. Sem eles, a separação seria realmente uma loucura, um plano inclinado, escorregadio para os golpes militares. Felizmente, existem, mas tão delicados, que o seu funcionamento normal pressupõe estadistas não tanto de pulso de ferro, como de caracter, cultura e sagacidade.

Mas examinemos as soluções. O primeiro conflito se verifica na estatuição das leis. No regime parlamentar, sendo o executivo praticamente uma comissâo da Camara dos Deputados, não se compreende nem sanção nem veto aos projetos de lei do parlamento. O parlamento elabora a lei de acordo com o gabinete. Resta ao chefe do executivo apenas o trabalho da promulgação e da publicação. A promulgação para autenticar o texto votado pelas casas do legislativo. A publicação da lei para o conhecimento de todos. Os conflitos, pois, não são de esperar. No regime presidencial, porém, os conflitos são possiveis. A elaboração das leis é objeto da competência de ambos. O executivo póde apresentar projetos de lei, e, em certas matérias, o projeto é sempre de sua iniciativa. Mas, além da apresentação de projetos de lei, cabe ao executivo sancionar ou vetar, no todo ou em parte, ou só no todo, os projetos das leis, aprovados pelas câmaras. Sancionando-os, não ha conflito. Mas si vetá-los?

Aqui, duas hipóteses se podem dar: ou as câmaras legislativas se conformam com o veto, ou não. Em ambas as hipóteses, ha soluções para o conflito. Na primeira, pela conformidade do legislativo com o executivo que terá reconsiderada a sua atitude. Na segunda, mantendo a sua atitude 
anterior, e, neste caso, é o executivo que se conforma com o legislativo.

De sorte que, embora coopere o executivo com o legislativo, cabe a este a palavra final em matéria de estatuição de leis. A cooperação dos dois órgãos em matéria legislativa não exclue a supremacia do parlamento.

Agora, os atritos em matéria da política do governo. A orientação geral que o chefe do executivo imprima aos negócios públicos, póde repercutir desfavoravelmente nas câmaras legislativas. Não se trata de crimes que o governo perpetre. Mas de direção opinativa onde ha margem para largos poderes discricionários. Como resolver, nesta emergência, a discórdia? Si o regime fôr parlamentar, nada mais facil. A queda do gabinete, e conseqüente organização de um novo põem logo de harmonia o legislativo com o executivo. Mas si o regime for presidencial, a solução da queda de goververno não tem logar. Dimitir-se o chefe do executivo por imposição do parlamento, seria a subordinação do órgão executivo ao legislativo, e lá se iria a separação dos poderes. Não é, pois, solução, mas golpe de violência. Renova-se o gabinete no regime parlamentar. Mas no presidencial, em que não ha gabinete responsavel pela orientação geral do governo perante o parlamento? Em rigor, não ha mesmo ministérios, não se póde dizer que exista gabinete, mas ministros ou secretários do estado, isolados, da confiança pessoal do chefe do executivo. Neste caso, como harmonizar os poderes, sem quebra da independência recíproca?

Ainda aqui, cumpre distinguir, na orientaçã்o geral dos negócios públicos, internos ou externos, aqueles que se não podem consumar sem a cooperação do parlamento, ou de uma das suas câmaras. Quando Wilson, presidente dos Estados-Unidos, empenhou o seu país, em 1918, nos compromissos da Liga das Nações, o senado recusou ratificar a sua política exterior. Abriu-se, evidentemente, um desacordo. Mas a solução constitucional foi dada sem quebra de independência recíproca. Prevaleceu o parecer do senado. Só por um processo seria possivel triunfar o parecer do presidente da- 
quela República na sua política contrária ao parecer do senado. Seria, na renovação do mandato seu e dos senadores, eleger o povo maioria de senadores que estivessem com a política internacional do presidente. Não foi o que se verificou. Na successão de Wilson, o povo elegeu para a presidência da Republica candidato da política oposta. E assim se encerrou o dissídio, sem quebra da independência dos poderes, e na mais perfeita consagração da democracia. Falou, no caso, por último quem tinha, afinal, de suportar as conseqüências da política que predominasse.

Nos demais casos, isto é, na política do governo que se consuma sem audiência do parlamento, ainda que este entenda estar em mau caminho o governo, predomina a vontade do executivo. Si o regime fosse parlamentar, o governo seria a vontade do parlamento. Mas, sendo presidencial o regime, a divergência de opinião, que surja, não tira ao executivo o seu império. O mais a que póde recorrer o parlamento, é apelar para a decisão das urnas. Na sucessão do chefe do executivo, o povo ou reelegerá o presidente, consagrando a sua política, uu o derrotará nas urnas, condenandoa. A palavra final será a dos governados, como é natural e justo.

Para casos tais, poder-se-ia ainda apelar, sem ofensa aos bons princípios, para o referendo popular. 0 mal deste apelo, si repetido, estaria no excesso de agitação popular, sempre que a maioria dos representantes entender opor-se ao presidente. A experiência dos Estados-Unidos consagra por sábia a solução popular das eleições gerais.

E' o que Hauriou denomina o poder de sufrágio. Excluindo o judiciário da categoria de poder, ele considera $o$ de sufrágio como o terceiro poder.

E' o poder a quem incumbe a solução final nos atritos entre o executivo e o legislativo.

Quando a luta se exaspera entre o parlamento e o governo, a solução imediata, no regime parlamentar, é a dissolução da câmara dos deputados, para que o povo decida. 0 poder de sufrágio tem, neste caso, a palavra final. 
Passemos, agora, a examinar os atritos possíveis entre o judiciário e os dois outros poderes.

Tais atritos só podem ser de natureza judiciária. São excluidas as questões estrictamente políticas, isto é, as que se decidem, não pelo critério da lei, mas pelas conveniências atuais. Um juiz não póde, por exemplo, revogar uma lei ou nomear um embaixador, decretar o estado de sítio, ou dissolver o parlamento. A missão do juiz é resolver uma questão de direito por provocação da parte, ou mesmo "ex-officio". Só no exercício desta missão é que poderiam surgir atritos. Atritos com o governo, ou atritos com o parlamento. E' o caso, por exemplo, da concessão de uma ordem de "habeas. corpus" O governo prende certo indivíduo. Recorre o preso ou alguém por ele ao tribunal, e o tribunal, julgando ilegal a prisão, ordena a soltura da vítima. 0 choque é inevitavel. Mas já resolvido em si mesmo. No caso prevalece a resolução judiciária.

Dir-se-á que o tribunal póde errar, e não seria prudente, por isto, dar-lhe faculdade de decidir sem apelo, contra atos do governo. Seria implantar a ditadura judiciária.

Em primeiro logar, o que o tribunal faz em tais casos, é interpretar a lei, examinar os fatos, e aplicar a lei aos fatos, para restabelecer uma situação de direito. E' a missão judiciária. Si, interpretando a lei, si, examinando os fatos, errar, paciência. Tambem póde errar o governo cujos atos sejam anulados pela intervenção judiciária.

Em segundo logar, como haver por ditadura a supremacia do judiciário em matéria jurisdicional? Alguém tem de falar por último nas cousas humanas. Si não for o tribunal na solução das questões de direito, será outro órgão. E si o falar por último implica em ditadura, quem quer que fale por último, terá de exercer tal ditadura. $O$ argumento prova, pois, demais. Si, mesmo assim, verificar o povo que, com a supremacia judiciária na aplicação de certa lei, ha danos a lamentar, nada lhe impede de alterar a lei que cause tal dano, seja por danosa em si, ou porque os tribunais a estejam interpretando mal. O juiz não estatue, não derroga nem 
revoga a lei. Fá-la cumprir na solução das questões de direito. Logo, ainda por este lado, a argüição da ditadura judiciária sôa falso. Si não se quizer que, contra atos do governo, fale a justiça sem apelo, o que primeiro importa é não criar o governo a questão de direito com os cidadãos. $\mathrm{Da}$ parte do governo, bastará que respeite, por sua vez, as leis.

E si o atrito for com o poder legislativo?

Elaborou o congresso uma lei, que se acôima de inconstitucional. Recorrem os prejudicados aos tribunais, para que resolvam a questão de direito suscitada. Contraditando-se com a lei constitucional uma lei ordinária, não póde o tribunal eximir-se ao dever de amparar a lei constitucional que a ordinária não derrogá. E' conflito que não se póde jamais verificar onde a constituição não for rígida, isto é, onde a lei constitucional puder ser elaborada pelo mesmo processo de elaboração da lei ordinária. Porque, neste caso. a lei posterior revoga sempre os textos legais em contrário, sem distinção. Conflitos desta natureza só são possiveis nos regimes de constituições rígidas.

Enquanto se elaborava a lei, o poder judiciário se manteve em silêncio. Não lhe cumpria agir. Só quando lhe baterem às portas, invocando a proteção constitucional, é que o tribunal exerce o seu mistér de resolver estas questões de direito. E, resolvendo-as com aplicar a constituição contra leis ordinárias, é como si declarasse nulas as leis ordinárias. Si aplicasse a lei ordinária, é como se declarasse nula a lei constitucional. De qualquer fórma, terá de preferir uma. E, como no regime das constituições rígidas, não se aplica, em matéria constitucional, o princípio de que qualquer lei posterior revogue a anterior, terá o juiz de pôr embargos à ação inconstitucional do legislativo.

Quer-se, porém, como convém, evitar táis conflitos? Nada mais facil. Cumpra o legislador o seu dever, sem sair da competência que tenha. Não tem competência para revogar, em processo de elaboração comum, preceito constitucional. E si o tenta, exorbita. O que fizer, não é razoavel que preva- 
leça. Não tem o legislativo competência para dar-se competência contra a constituição que lh'a negue.

E, por aqui, se vê bem claramente como é possivel estabelecer, no aparelhamento do estado, a independência dos poderes, nos termos expostos, compativel com a harmonia entre eles, como peças de uma só máquina, cada uma das quais com função própria, e todas em harmonia para a mesma finalidade. Não ha conflito para o qual não se encontre solução legal. Não é necessário apelar para as revoções, ou os golpes de estado. No mecanismo da separação de poderes, concebida à maneira da grande república do norte, e não à da metafísica de 1789, o equilíbrio é sempre possível, sem desprestígio do estado, e para maior benefício de todos.

Com a simples distribuição de funções e sua hierarquização ao poder executivo, não ha garantia da liberdade. Distribuem-se as funções, repartindo-as com os vários órgãos. e pondo-as em colaboração recíproca, com um propósito distinto da separação de poderes. A distribuição de funções se inspira na necessidade de assegurar ao estado eficiência e continuidade de vida. A separação, porém, de poderes se inspira na necessidade de garantir a liberdade contra os abusos de poder, atalhar os golpes de estado, e prevenir as guerras civis. 